TI 2000-080/3

Tinbergen Institute Discussion Paper

Themes, Approaches, and Differences with Environmental Economics

J eroen C.J .M. van den Bergh 
Tinbergen Institute

The Tinbergen Institute is the institute for economic research of the Erasmus Universiteit Rotterdam, Universiteit van Amsterdam and

Vrije Universiteit Amsterdam.

Tinbergen I nstitute Amsterdam

Keizersgracht 482

1017 EG Amsterdam

The Netherlands

Tel.: +31.(0)20.5513500

Fax: $\quad+31 .(0) 20.5513555$

Tinbergen I nstitute Rotterdam

Burg. Oudlaan 50

3062 PA Rotterdam

The Netherlands

Tel.: $\quad+31 .(0) 10.4088900$

Fax: $\quad+31 .(0) 10.4089031$

Most TI discussion papers can be downloaded at

http://www.tinbergen.nl 


\title{
Ecological Economics: Themes, Approaches, and Differences with Environmental Economics
}

\author{
Jeroen C.J.M. van den Bergh \\ Department of Spatial Economics \\ Free University \\ De Boelelaan 1105 \\ $1081 \mathrm{HV}$ Amsterdam \\ The Netherlands \\ Fax: +31-20-4446004 \\ Email: jbergh@econ.vu.nl
}

Revised version, September 2000 


\begin{abstract}
This article provides a short overview of the main themes of ecological economics (EE). It is argued that EE provides a platform that fosters multidisciplinary environmental research by bringing together the core contributing disciplines economics and ecology. In addition, EE is regarded as a pluralistic approach to environmental research that can be set opposite to, and has indeed developed as a response to, traditional environmental and resource economics. A comparison of the two fields is presented to clarify the essential differences between them. In addition, specific themes are examined in more detail. These include: sustainable development; the growth debate; international trade; dynamic processes; and behaviour and policy.
\end{abstract}

\title{
Key words
}

Comparison; Environmental policy; Growth debate; Individual behaviour; International trade; Multilevel dynamics. 


\section{Background}

The field known as "Ecological Economics" (EE) was founded at the end of the 1980s. ${ }^{1}$ It immediately attracted a large number of researchers from various disciplinary backgrounds that were involved in the study of environmental issues. EE very quickly developed into a field that was successful in several respects (Costanza and King 1999): many publications and citations to these; regular conferences and workshops; and communication among disciplines and countries, as well as between universities and other organisations. EE integrates elements of economics, ecology, thermodynamics, ethics, and a range of other natural and social sciences to provide an integrated and biophysical perspective on environment-economy interactions, aimed at contributing to structural solutions to environmental problems. The core of EE can be associated with the goal of sustainable development, interpreted as both intra- and intergenerational equity; the view that the economy is a subsystem of a larger local and global ecosystem that sets limits to the physical growth of the economy; and, a methodological approach based on the use of physical (material, energy, chemical, biological) indicators and comprehensive systems analysis.

EE provides a forum for multidisciplinary environmental research as well as an alternative view and approach to traditional environmental (and resource) economics (ERE). Various economists, ecologists and environmental researchers have been dissatisfied with the way in which environmental problems and policy are studied by ERE. ${ }^{2}$ On the one hand, ecological economics offers criticism of the ERE approach, and, on the other, it tries to develop and apply alternative methods and approaches. ${ }^{3}$ Nevertheless, EE has perhaps been most successful in promoting multidisciplinary research in which natural scientists (notably ecologists) and social scientists (notably economists) join forces.

The economists K.E. Boulding, H.E. Daly, and N. Georgescu-Roegen, and the ecologists C.S. Holling and H.T. Odum are considered to be the intellectual founders and antecedents of EE. Martinez-Alier (1987), Christensen (1989) and Costanza et al. (1997a, Chapter 2) discuss the relevance for EE of ideas of early - and some almost forgotten - writers like P. Geddes, A. Lotka, J.S. Mill, F. Soddy and many others. Finally, specific writings by economists and ecologists have directly or indirectly influenced authors and writings in EE; an incomplete list of these fundamental publications is: Ayres and Kneese (1969), Ciriacy-Wantrup (1952), Clark (1973), Costanza (1980), Cumberland (1966), Ehrlich (1968), Galbraith (1958), Hardin (1968), Hueting (1974/1980), Isard (1969, 1972), Kapp (1950), Leontief (1970), Martinez-Alier (1987), 
Meadows et al. (1972), Mishan (1967), Norgaard (1984, 1989), Page (1977), Vitousek et al. (1986), and some of the literature mentioned in the next paragraph.

A short discussion of the main players can give the reader a feel for the issues that gave rise to the development of EE. At the end of the 1960s, H.E. Daly proposed the idea of a "steady state economy", associated with the objective to minimise the use of materials and energy ("throughput") in the economy (Daly 1968, 1977/1991). This was an essential contribution to the longstanding "growth debate" (see Section 4). Daly has also written extensively about the maximum physical scale of the economy, international trade, and sustainable welfare indicators (Daly 1992; Daly 1999a; Daly and Cobb 1989; Daly 1996). In particular, he can be characterised as someone who fosters communication and discussion in science on issues relating to growth, economic theory, thermodynamics, population, and more recently globalisation (see especially Daly 1999b). K.E. Boulding was already famous and respected in economics ${ }^{4}$ before he showed an academic interest in environmental issues. He is best known in EE for an article in which he contrasts the "cowboy economy" and the "spaceship economy" (Boulding 1966). Within the cowboy economy - a metaphor for the local or national open economy - people are little worried about the quality of environment and nature, and observe merely local environmental problems. Therefore, they regard migration and shifts to new resources as solutions. Conversely, the spaceship economy - a metaphor for the world as a whole - is characterised by limited material and food supplies. The survival strategy in this case is economic use of materials, energy and environment, and maximisation of recycling of substances, materials and products. This spaceship metaphor reflects the implications of the mass-balance principle, and can also be seen as a precursor of the modern view on global environmental problems. Boulding is renowned for often employing metaphors and analogies from biology (Boulding 1978) and other sciences (Boulding 1970). The statistician-economist N. Georgescu-Roegen is best known in economics for his contributions to utility theory and activity analysis. In the 1960s and 1970s he wrote seminal publications on the foundations of economics, which were very critical towards standard neoclassical economics (Georgescu-Roegen 1966, 1971 and 1976). In particular, his interpretation of economic processes in the context of thermodynamics has generated many responses and debates in EE (see Gowdy and Mesner 1998; and various contributions in a special issue of Ecological Economics (Daly, 1997)). C.S. Holling has perhaps been the ecologist who has had the greatest direct influence on EE. His ideas on ecosystem stability and resilience 
(Holling 1973) are the most referred to notions in theoretical ecology, which have even been picked up by economists (see Levin et al. 1998, and Perrings 1998). These notions have also been translated to the context of biodiversity (Holling et al. 1995). Holling has also developed the idea that (terrestrial) ecosystems do not necessarily follow a pattern of succession towards a climax, but instead can go through a repeated cycle (Holling 1986). In addition, he has influenced approaches to integrated modelling and adaptive management (Holling 1978, and more recently Gunderson et al. 1995). Finally, the systems ecologist H.T. Odum has influenced EE through his EMERGY analysis approach (Odum 1971), which has been applied to EE issues by many of his students - including R. Costanza, C. Hall and I.-M. Jansson. EMERGY analysis traces all environmental products and services back to solar energy, which provides the energetic basis of ecosystem processes and functions. Odum himself has even proposed applying the method to the integrated study of economic-ecological interactions ranging from local to global scales (e.g., Odum 1987). An ambitious and interesting study in this vein is by Zuchetto and Jansson (1985). EMERGY analysis has its strong proponents and opponents (for a short introduction, see Herendeen 1999).

EE is nowadays clearly present on an institutional level, with an international society (see http://isee.ecoeco.org), various regional societies (US, South America, Canada, Europe, Russia, Asia/Australië), and an academic journal (Ecological Economics). In addition, various books (Costanza et al. 1996, 1997a and b; Edward-Jones et al. 2000; Jansson et al. 1994; Krishnan et al. 1995; van den Bergh 1996; van den Bergh and van der Straaten 1994, 1997; Cleveland et al. 2000; Munasinghe 2000) and articles (Turner et al. 1997; Martinez-Alier 1999; Spash 1999; Turner 1999) have appeared that offer a variety of perspectives on EE. These indicate that EE is pluralistic rather than striving towards a dominant and general theory. As a result, EE is internally much more heterogeneous than standard ERE, where the neoclassical paradigm defines the direction of research.

This article discusses the main themes within EE (Sections 3 to 7). These include: sustainable development, the growth debate, international trade, dynamic processes, and behaviour and policy. First, however, Section 2 explores the opposition which some perceive between EE and ERE. Section 8 concludes.

\section{Ecological versus traditional environmental economics}

The difference between EE and ERE relates to a number of issues. These are discussed below. 
The core of ERE is the theory of (negative) externalities or external costs. This considers environmental degradation and use of unpriced natural resources as a negative effect outside the market by one economic agent on another, without any form of compensation taking place. This implies that the environmental problem is cast in terms of an interaction between people (economic agents), that is, nature and environment are only implicitly described. EE is instead more interested in an explicit modelling of people-environment or economic-ecological relations, by mapping out cause-effect relationships and dynamic processes within the environment (hydrological, chemical, physical and ecological). According to Turner et al. (1997) this is due to the fact that EE is more closely related to traditional "resource economics", notably concerning renewable resources like fish, forests and water (Clark 1990, Neher 1990), than to environmental economics in a narrow sense ("economics of pollution").

Another important opposition is between scale and allocation. ERE is aimed at optimal allocation and thus efficiency of use of scarce means (including resources). Environmental problems are translated through the concept "externality" (or "external effect" or "external cost"). The objective is to find the optimal level of an externality, which follows from striving towards optimal social welfare or Pareto efficiency. The latter is defined as a situation in which an improvement in the welfare of any individual cannot be achieved without a welfare loss for someone else. ERE considers natural resources (gas, oil, fish, timber), environmental quality, services rendered by the environment, and nature as scarce resources to which (optimal) allocation theories are applicable. Daly (1992) has since long argued that economists have neglected the issue of an optimal physical scale or size of the economy, and instead have focused completely on allocation issues. In the context of environmental sustainability and sustainable development goals, the scale problem has received much attention, shown also by academic and policy discussions about indicators for determining the physical dimensions of the economy (Gibson et al. 2000; see also Section 5).

EE has chosen sustainable development as its central concept. This is subsequently approached both qualitatively and empirically, with particular attention for spatial scales (ranging from local to global). Within ERE, sustainable development is usually regarded as being identical to sustainable growth, which is studied with general and abstract models that avoid any reference to historical and spatial aspects, as well as specific characteristics of countries. ERE does not seem to take absolute physical limits to growth as seriously as EE, and regards the problem of a 
"maximum scale" of the economy as irrelevant. A special point of attention in EE is the structure and institutional context of developing countries. Linked to this is a more serious contribution from, and more interaction with, scientists from developing countries (for instance, the locations of the ISEE World Congress alternate between the North and the South). In addition, EE generally assumes a longer time horizon than ERE and, consistent with this, pays more attention to cause-effect chains, interactions and feedback between natural and human-economic systems. The concept "co-evolution" is relevant here, as it is considered to reflect a mutual influence of economic and environmental systems that creates a unique historical development. In this sense $\mathrm{EE}$ is closer in spirit to evolutionary than to neoclassical economics. Evolutionary economics is characterised by concepts like path dependence, historical accidents and irreversibility of changes. Path dependence implies that possibly inferior technologies can become dominant as a result of unforeseeable historical events in combination with economies of scale, due, inter alia, to positive network externalities (witness the market dominance of Microsoft operating systems). An implication of co-evolution is that the market does not necessarily lead to a selection of (in a neoclassical sense) optimal technologies, production activities, and use of space, even when prices are "correct". Therefore, EE considers systems, including markets, as adaptive and coincidental rather than optimal.

The main goals and criteria for evaluating developments, policies and projects differ between EE and ERE. The dominant criterion of ERE is "efficiency" (or sometimes a more limited version, such as cost-effectiveness). Most economists would regard this as something trivial and hardly ethical. Nevertheless, it presumes that "more is always better". Furthermore, whereas in ERE distribution and equity are secondary criteria, EE emphasises (basic) needs, North-South welfare differences, and the complex link between poverty and environment. In addition, $\mathrm{EE}$ is best characterised by the "precautionary principle", linked to environmental sustainability, with much attention to "small-probability-large-impact" combinations. 5 " This precautionary principle is closely related to a concern for instability of ecosystems, loss of biodiversity, and environmental ethical considerations ("bio/eco-centric ethics"). "Efficiency" is of secondary concern in EE. "Distribution" is often considered as a more important criterion for evaluating policies and changes than efficiency. In addition, some argue that it is impossible to analyse distribution and efficiency separately. This would mean that the main tool of ERE: 
namely, equilibrium analysis, which assumes that efficiency can be assessed independent of distribution, is inaccurate at best (Martinez-Alier and O’Connor 1999).

ERE focuses on value dimensions: namely, utility and welfare in theory, and costs and benefits in practice. Unlike neoclassical economics, EE does not regard a total valuation of changes in ecosystems as the sum of private values. For the latter takes no account, or insufficiently, or insufficient account, of internal environmental system functions, "life-support" functions, future generations, and non-instrumental existence values. EE is inclined to add criteria to the economic values in the context of decision making concerning management of and changes in ecosystems. The terminology "ecosystem health" is used to cover aspects like productivity, stability and resilience of ecosystems, biodiversity (genes, species, ecosystems), and the quality of the abiotic environment (Costanza et al. 1992; see also the journal Ecosystem Health).

Next, EE criticises social objectives such as those formulated within ERE, notably the utilitarian approach to intergenerational welfare. Alternatives are a Rawlsian principle of justice ("maximin criterion") (Rawls 1972), or a minimum welfare level encompassing (basic) needs (Stern 1997). This is, of course, all just theory and can hardly be operationalised. In practice, the striving for GDP growth at a macro-level and cost-benefit analysis at a project level remain. Which alternatives are offered by EE in this respect? Some have pleaded in favour of physical or ecological indicators (material intensity per unit of service (MIPS), “ecological footprint”, "ecosystem health"), and others in favour of a multidimensional analysis based, for example, on multicriteria evaluation (Munda et al. 1994, Martinez-Alier et al. 1998). In addition, EE seems to discard consumer sovereignty when giving priority to the interest of systems above the freedom of choice of individuals, as in environmental movements like "deep ecology".

Within EE, a far-reaching integration of economics with insights from ecology is proposed. Ecology is the area within biology that studies the relation of living organisms with their biotic and abiotic environment. It distinguishes various dynamic processes in ecosystems: namely, population growth, ecosystem succession, changes of natural equilibria, and evolution (see Section 6). An operational technique for the aimed integration is ecological-economic modelling at local, regional and global scales (see Braat and van Lierop 1987; van den Bergh 1996; Costanza et al. 1993).

EE has often expressed a dissatisfaction with the strict and fixed assumptions in traditional economic theory with regard to individual behaviour. They are usually summarised in 
the notion of "(unbounded) rationality" and models of maximisation of profit (firms or entrepreneurs) and utility (households or consumers). These models underlie the analytical insights obtained by ERE with respect to economic valuation and environmental policy. Various branches of economics and closely related disciplines, such as evolutionary economics, institutional economics, experimental economics, psychology and sociology, have presented theoretically- and empirically-based critiques on these models. Although EE seems to be sympathetic to these critiques, it has generated few alternative approaches thus far. Van den Bergh et al. (2000) discuss the neoclassical approach, survey the criticism of it, and present a first analysis of the implications of alternative models of individual behaviour for environmental policy. Such models include, among others, 'satisficing', lexicographic preferences, relative welfare, habits and routines, imitation, reciprocal behaviour (including various types of altruism), changing and endogenous preferences, and various models of behaviour under uncertainty. Spash and Hanley (1995) argue that lexicographic preferences offer an explanation for some of the problems met in economic valuation studies, notably that certain people are sometimes unwilling to make trade-offs between income compensation and environmental change (see also Blamey and Common 1999).

Table 1 summarises the main differences between EE and ERE. ${ }^{6}$ Note that this presents a somewhat simplified picture. Obviously, hybrid approaches are possible, especially in view of EE being diverse and not characterised by a univocal theory. Moreover, some of the shortcomings of ERE (according to EE) can be resolved within the traditional theoretical framework of neoclassical economics. For instance, environmental externalities can be modelled by describing dynamic causality relationships on the basis of ecological insights. Crocker and Tschirhart (1992) show that it is possible to incorporate descriptions of ecosystems within a wider framework of general equilibrium with externalities. Finally, the objective of sustainable development is also broadly supported nowadays by ERE, although definitions and interpretations are not always consistent with those adopted by EE (see Section 3).

In evaluating the differences between $\mathrm{EE}$ and ERE, it is interesting to note that one of the most influential biologists of this century, E.O. Wilson, has recently introduced the criterion "consilience" as a measure of good science (Wilson 1998). This denotes that the methods and starting points of one scientific discipline need to be consistent with the accepted insights of other disciplines, across all areas of science, including the natural and social sciences. Gowdy and 
Ferrer-i-Carbonell (1999) offer a discussion of "consilience" between biology and economics, the two most important disciplines supporting EE, in order to examine to what extent economists and ecologists have influenced each other's way of thinking about environmental problems and their solutions. Within EE, a dominant idea is that ERE approaches need to be made coherent with findings in ecology and thermodynamics. Nevertheless, this is complicated due to distinct research traditions and methods (Shogren and Nowell 1992). In addition, consistency with insights from technical and other social sciences is also necessary. Particularly with regard to modelling consumer and firm behaviour for environmental policy analysis and monetary valuation, insights from psychology and sociology could be useful.

\section{Table 1. Differences in emphasis between EE and ERE.}

\begin{tabular}{ll}
\hline Ecological Economics & Traditional Environmental and Resource Economics \\
\hline 1. Optimal scale & 1. Optimal allocation and externalities \\
2. Priority to sustainability & 2. Priority to efficiency \\
3. Needs fulfilled and equitable distribution & 3. Optimal welfare or Pareto efficiency \\
4. Sustainable development, globally and North/South & 4. Sustainable growth in abstract models \\
5. Growth pessimism and difficult choices & 5. Growth optimism and "win-win" options \\
6. Unpredictable co-evolution & 6. Deterministic optimisation of intertemporal welfare \\
7. Long-term focus & 7. Short to medium term focus \\
8. Complete, integrative and descriptive & 8. Partial, monodisciplinary and analytical \\
9. Concrete and specific & 9. Abstract and general \\
10. Physical and biological indicators & 10. Monetary indicators \\
11. Systems analysis & 11. External costs and economic valuation \\
12. Multidimensional evaluation & 12. Cost-benefit analysis \\
13. Integrated models with cause-effect relationships & 13. Applied general equilibrium models with external costs \\
14. Bounded individual rationality and uncertainty & 14. Maximisation of utility or profit \\
15. Local communities & 15. Global market and isolated individuals \\
16. Environmental ethics & 16. Utilitarianism and functionalism \\
\hline
\end{tabular}

\section{Sustainability and sustainable development}

There are various definitions of sustainability and especially of sustainable development (see Pezzey 1989; Toman et al. 1995; van den Bergh and Hofkes 1999; and Ayres et al. 2000). Notably, the opposition between strong and weak sustainability has received much attention in the last few years. Weak sustainability has been defined on the basis of the concepts "economic capital" and "natural capital". Economic capital comprises machines, land, labour and 
knowledge. Natural capital covers resources, environment and nature. Under weak sustainability one strives for maintaining "total capital", defined as the "sum" of both types of capital. This allows the substitution of natural capital by economic capital, as has been analysed in economic growth theory (Solow 1974 and 1986, Hartwick 1977). Strong sustainability, by contrast, requires that every type of capital is maintained separately. ERE starts from weak sustainability, which emphasises a large degree of substitution of inputs in production and the economy as a whole. This has been criticised by EE (see Ecological Economics vol. 22, 1997). Within EE, usually some type of strong sustainability is emphasised, which is operationalised through goals such as protection of critical ecosystems, striving for at least a minimum area of nature, or maintenance of biodiversity.

Within EE, frequently another aspect of (un)sustainability is pointed out: namely, the stability and resilience of ecosystems. Perrings (1998) mentions two alternative readings: one is directed at the time necessary for a disturbed system to return to its original state (Pimm 1984); the other is directed at the intensity of disturbance that a system can absorb before moving to another state (Holling 1973). In line with the latter interpretation, resilience has been phrased "Holling sustainability", as opposed to weak "Solow-Hartwick sustainability" (Common and Perrings 1992). As a result, EE studies pay relatively more attention to the sensitivity of ecosystems at a micro level, often in applied studies, whereas ERE extends economic growth theory with environmental variables, emphasising determinism and approximate long-term trends in a macro-approach that lacks any micro-detail. From this perspective, EE and ERE approaches to sustainability can give rise to both complementary and contradictory insights.

\section{The "growth debate"}

The discussion surrounding sustainable development can be considered as a "terminology game" that does not resolve the older "growth debate" but just disguises it (see van den Bergh and de Mooij 1999). The growth debate can be characterised by three main questions: Is economic growth desirable? Is it feasible? And, is it controllable?

Both the elaboration of and the answers to these questions differ between EE and ERE. With regard to the first question ERE seems to take for granted that economic growth increases social welfare. EE has generated some criticism on this assumption. Since social welfare is not unambiguously measurable, one can discuss endlessly what is a meaningful measure of welfare. ${ }^{7}$ In addition, one can ask about the relationship between material welfare beyond the level of 
satisfaction of (basic) needs. "Relative income", the income relative to the (national) income distribution, is more relevant for this purpose than absolute income, because people measure their material welfare against that of individuals in their social environment, which is local or national. This perspective suggests that a redistribution of income can have a more significant influence on social welfare than a continuation of growth.

For addressing the second question in the growth debate: "Is economic growth feasible?", the distinction between weak and strong sustainability is useful. ERE is in general more optimistic than EE. Notably, it seems to have much confidence in price and market processes that steer behavioural responses from producers and consumers. To take just one example, scarcity of natural resources is argued to lead through price information to responses in terms of substitution, savings and recycling of materials, and to technological innovations at process and product levels. EE is more pessimistic, or, better perhaps, more "precautionary" about such responses, which is often accompanied by references to thermodynamics. Furthermore, EE states that damages to nature and environment have assumed such proportions that continuing growth will almost surely lead to ecological disasters. In this context, soil erosion, deforestation, enhanced global warming and loss of biodiversity are regarded as the most urgent problems. EE expresses serious worries about the resilience of ecosystems, which depends on the complex connection between global bio-geo-chemical processes and "life-support" functions of the biosphere, which are presently under severe pressure from human activities. In terms of methods of analysis of growth-versus-environment, ERE has recently focused attention on partial empirical analysis through studies that examine de-linking between certain environmental indicators and income per capita ("green Kuznets curves"; see de Bruyn and Heintz 1999). Instead, EE relies more on complex systems analysis that incorporates feedback mechanisms between economy, growth, environmental quality, natural resources, population growth, welfare level and health status. ${ }^{8}$

The last question in the growth debate is: Can we control or direct economic growth? Since most governments and central banks are committed to realising a positive rate of growth, it is hard to say whether it is feasible - policy-wise and politically - to arrange a zero or negative rate of growth. From an economic perspective an important derived question is whether without growth other macroeconomic goals, such as full employment and price stability, can be reached. Within EE, no clear-cut answers to these questions have been formulated, due to the fact that the issue of controllability of economic growth has been largely neglected. Obviously, if this 
question remains unanswered or has a negative answer, any discussion of the other questions is a waste of time. Within ERE, the controllability issue is not considered at all, which is consistent with its positive answers to the other two main questions in the growth debate.

\section{International trade and environment}

The development of ERE during the 1990s is characterised by considerable attention for the international dimension of environmental problems and policy, in particular the relationship between international trade and environmental policy. The classical trade theories of Ricardo and Heckscher-Ohlin state that, on the basis of comparative advantages, international trade increases the welfare of all contributing countries. Daly and Cobb (1989) are, however, of the opinion that these insights no longer hold as the assumption of immobile capital flows is no longer satisfied. In their view, the modern world is characterised by free capital flows (capital mobility). This viewpoint suggests the need for a fundamental discussion about the relevance of traditional trade theories for formulating environmental policy. Daly and Cobb conclude, by referring to statements of Maynard Keynes, which reflect the idea that production of products should, whenever feasible, take place in the own country. An additional argument for this view is that sustainability at a regional scale can be better controlled in an autarchic than in an open region.

In order to "measure" regional unsustainability Wackernagel and Rees (1996) have formulated the concept of the "ecological footprint" (EF) and applied it to countries (as well as other spatial units). They conclude that many countries, in particular small ones, use directly and indirectly more surface area than is available inside their national boundaries. Evidently, this is compensated by international trade. Wackernagel and Rees try to argue on the basis of the EF that autarchy is to be preferred to a trading region. Van den Bergh and Verbruggen (1999) criticise the EF indicator and applications:

- the EF is an example of "false concreteness": the resulting land area is hypothetical and too crude a measure of various types of environmental pressure;

- the EF method does not distinguish between sustainable and unsustainable land use, notably in agriculture;

- aggregation of different environmental problems occurs through an implicit weighting that lacks any justification;

- $\mathrm{CO}_{2}$ emissions due to burning fossil fuels are translated, on the basis of an arbitrary 
"sustainability scenario" (forestation to capture $\mathrm{CO}_{2}$ ), into hypothetical seizure of land.

Comparing the EF of countries with their available land area implies that national consumption should remain within boundaries defined by national production opportunities, which is an ex ante "anti-trade" bias. This is not only normative but very arbitrary. Relatively small or densely populated countries (in terms of available land area) trade more relative to their national income. Indeed, spatial scales indeed correlate strongly with the proportion of trade in consumption. For illustration: cities trade $100 \%$ of their consumption; and the world as a whole is autarchic.

Trade has various negative impacts in social and political dimensions, such as weakening community structures, and confusing individual human perceptions of the ecological impact of individual consumption decisions. On the other hand, one can also foresee various negative consequences of minimising international trade, such as the worsening of international relationships between countries, the destabilisation of international trade agreements and institutions, even trade wars and other conflicts, and a lack of diffusion of knowledge and technology. The fundamental question of more versus less trade cannot be reduced to the calculation of an aggregate indicator, but needs to be discussed in a framework that allows a subtle comparison of the advantages and disadvantages of trade. ${ }^{9}$ This needs to pay explicit attention to the diversity of economic, ecological, sociological and political insights about international trade relations. To date, EE has contributed mainly to analysing the implications of international trade for regional cultures and communities (Daly and Cobb 1989).

\section{A hierarchy of dynamics}

In Section 2, it was already indicated that EE is more closely related to resource economics than to the "economics of pollution". Perhaps this is best illustrated by the fact that simple models from population biology (ecology) have been incorporated in ERE theory of renewable resources. Specific models have been developed for the analysis of fisheries, forestry and water management.

EE uses more information from ecology for modelling human influences on nature and environment than ERE (see Folke 1999). This includes population dynamics based on interactive populations, such as symmetric (competition, mutualism) and asymmetric (herbivore plant, parasite host, predator-prey) relationships, on multiple generations, or on spatially disaggregated (meta-)populations. Ecosystem models add relationships between biotic and abiotic processes to 
these population models, for example the influence of nutrients on the presence and growth of certain plant species. An additional level of dynamics is ecosystem succession, by which the composition, structure and functions of an ecosystem change until a climax system has been reached. An alternative view proposes a cyclic process without any climax. The theory often referred to in this context is the "four-box model" for terrestrial ecosystems (Holling 1986). It depicts ecosystems and their changes in a two-dimensional diagram with "stored capital" (biomass) and "connectedness" (complexity of the foodweb) on the axes. Ecosystems can then go through four phases: "exploitation", "conservation", "release" and "reorganisation". The "release" phase, for instance, is triggered by forest fires, storms and outbreak of diseases.

The dynamics of ecosystems has given rise to a question about the stability and resilience of ecosystems. EE devotes much attention to this issue. At the moment, resilience is even examined as an analogy for the functioning of social systems (bureaucracy, politics, economy, etc.) (see Levin et al. 1998). In the above-mentioned "four-box model" management aimed at artificially prolonging a certain phase, notably "conservation", can reduce the resilience of the system. For example, checking small forest fires, which leave seeds intact, will result in an accumulation of forest biomass. This in turn will increase the probability of the occurrence of a large forest fire at a very high temperature, which in turn can destroy plant seeds and thus prevent the "reorganisation" phase from occurring successfully.

A last level of dynamics that is studied within ecology and EE is evolution. Within biology, evolutionary theory has provided the necessary integration of various subdisciplines, such as molecular biology, genetics, cell biology, physiology, development biology, and ecology. Within EE, (co-)evolution is regarded as a conceptual model for addressing the relationship between economy and environment in the long-run. This connects closely to a historical approach to the analysis of the interaction between economic development, environmental change, technology change and institutional change. Examples of such interactions are: the inception of the Industrial Revolution (Norgaard 1994; Wilkinson 1973); the historical transition from the hunter-gatherers era to primitive agricultural societies (Gowdy 1994, 1998); and, perhaps even the current wave of technological innovations in the areas of biotechnology and information and communication technology.

Important implications of this hierarchy of dynamic processes are as follows. In the first place, a sufficiently large disturbance by humans will not only create a temporary removal from 
an equilibrium, but will also lead to dynamic effects throughout the hierarchy of dynamics. This can have irreversible consequences, for example when ecosystem components and functions are lost.

The complexity of temporal dynamics often requires an explicitly spatial approach: for example, land use, water use, and diffuse pollution influence spatial cause-effect chains that bring about complex system dynamics in space and time. Especially in water-driven systems, like wetlands, a spatial approach is indispensable. This requires the use of much detailed information, which in turn causes aggregation problems, both in the description of processes and the evaluation of process outcomes.

\section{Individual behaviour and environmental policy}

EE criticises the points of departure of ERE with regard to individual behaviour but generally supports its central findings on policy, which can best be summarised as "correct prices". The criticism could, however, give rise to a study of alternative models of individual behaviour and their implications for environmental policy. The first results of such a research programme suggest that price instruments could certainly be less effective than is often taken for granted (van den Bergh et al. 2000). Furthermore, influencing preferences could become an important pillar of environmental policy aimed at realising long-run sustainable development (Norton et al. 1998). Normative objections against preference-oriented policies are outmoded; indeed, preferences have long been moulded through advertisements by private businesses for purely commercial interests. Nevertheless, environmental policies aimed at influencing preferences will be effective only if complementary instruments like environmental legislation and other types of environmental regulation are employed. For example, to reduce speeding by cars one can combine: downsizing of car engines, technical speed controllers on engines, prohibiting advertisements of fast cars, and obligatory driving-style courses.

A general difference between environmental policy according to EE and ERE, as indicated in Section 2, concerns the difference between the main goals. ERE focuses on internalising, or more precisely "optimising", external costs. Economic or market-based instruments fit well in this scheme as they provide incentives to individual producers and consumers that, according to the theory, lead to social efficiency ("marginal social costs equal marginal social benefits"). EE is aimed at sustainability and emphasises the precautionary 
principle in dealing with complexity (ecosystems), surprises (environmental disasters) and uncertain developments (climate change). Common and Perrings (1992) use a theoretical model to analytically illustrate that economic-ecological systems are not completely "observable" and "controllable" via prices and instruments that directly influence prices. In other words, price instruments fall short in the case of sustainability.

A number of instruments have been proposed to address the uncertainty and complexity surrounding ecosystems and sustainability. The notion of "safe minimum standards" (CiriacyWantrup 1952) points to the fact that efficiency means exploring the borders, whereas in many circumstances characterised by a large degree of uncertainty it would be better to take account of safety margins. A flexible instrument to do this is an "environmental bond" (Costanza and Perrings 1990). An investment or project that is surrounded by a great deal of uncertainty concerning environmental consequences is complemented by an insurance bond with a value equal to that of the maximum expected environmental damage. This bond functions as a deposit that is completely or partly refunded (with interest) depending on the amount of environmental damage that has resulted from the respective investment project. If environmental damages are nil, the entire deposit is returned; if there are actual or threatening negative environmental effects, the deposit serves to compensate or prevent damage. This instrument can, inter alia, be applied to land reclamation, investment in infrastructure, transport and treatment of hazardous (toxic, nuclear) substances, and location of agriculture and industrial activities near sensitive nature areas. As a consequence of environmental bonds, the (expected) private costs of such activities will increase, causing investors to make more conservative decisions, and so take account of environmental risks associated with human activities and investment projects.

Uncertainty within ERE is usually analysed by defining "states of the world" with associated probabilities, and maximising an expected benefit function. Fundamental or complete uncertainty, i.e. surprises, implies, according to EE, a different approach: namely, "adaptive management". This is based on the idea that management of complex and uncontrollable systems requires an interaction between experimental research, monitoring, learning processes, and policy choices, with the objective to learn from disturbances. This recipe has been applied to problems of fisheries, agriculture (ecological alternatives for pesticides), and forestry. Adaptive management also covers the interaction between various disciplines, experts and "stakeholders" (Holling 1978, Walters 1986, Lee 1993, and Gunderson et al. 1995). 
Finally, within EE, ideas can be found about economic structural change, notably, relating to "industrial ecology" and "industrial metabolism" (see Ayres 1998; Duchin et al. 1994; Graedel and Allenby, 1995; and Socolow et al. 1994). These emphasise spatial and sectoral adjustments of economic activities to realise a minimal environmental pressure caused by substance and material flows. For this purpose, a balance between such strategies as "dematerialisation", recycling and reuse, waste management and increasing durability of products is needed.

\section{Conclusion}

The themes discussed in the previous sections illustrate that a simple, one-dimensional opposition between EE and ERE is impossible. Moreover, searching for interactions and complementarity between EE and ERE seems fruitful. There certainly is overlap, partly because EE is not strictly confined. ERE represents a specialist, analytic approach, based on slowly and consistently extending knowledge and on strict assumptions regarding economic processes. EE is more pluralistic, aimed at the integration of existing insights. Although it is not always internally consistent, it is perhaps more creative and innovative at a conceptual level. Costanza et al. (1993) state that, in theory and modelling, a trade-off needs to be made between the criteria: generality, precision and realism. One could say that ERE emphasises generality and precision, whereas EE focuses on realism. Within ERE a theoretical consistency among all parts (insights) has resulted in an impressive "building". But if only a few of the foundations are taken away, the whole collapses. This does not hold for EE, where due to pluralism opposite opinions are much more common. ${ }^{10}$ Pluralism is very important for an open discussion of the advantages and disadvantages of scientific findings at the level of policy preparation and political decision making regarding environmental policy. ${ }^{11}$

EE can develop further along two paths. One involves more intense co-operation between natural and social scientists to influence each other's way of thinking and construct joint theories and models, in line with Wilson's notion of "consilience". In the view of many ecological economists, this is the main motivation for EE and the area where it can be most effective. The other path is to broaden the social science spectrum so as to provide for a real alternative paradigm to the neoclassical methodology of ERE. Some ecological economists seem to think that this is the way forward (see Spash 1999). Currently, however, EE may lack the necessary social science expertise to support such an ambitious goal. Therefore, it should link up with 
modern research on the relationship between individual and group behaviour (institutions and ethics) in biology, anthropology, communication science, economics, political science, psychology and sociology.

\section{Acknowledgements}

This is a translated and updated version of an article written for the lecture series "Environment and Economics" (Spring 1999), Ministry of Housing, Physical Planning and Environment, The Hague, The Netherlands. I am grateful to A. Ferrer-i-Carbonell and an anonymous reviewer for helpful comments on the introductory section.

\section{References}

Ayres, R.U., and A.V. Kneese, 1969. Production, consumption and externalities. American Economic Review 59: 282-97.

Ayres, R.U., 1998. Industrial metabolism: Work in progress. In: J.C.J.M. van den Bergh and M.W. Hofkes (eds.), Theory and Implementation of Economic Models for Sustainable Development. Kluwer Academic Publishers, Dordrecht.

Ayres, R.U., J.C.J.M. van den Bergh, and J.M. Gowdy, 2000. Weak versus strong sustainability: economics, natural sciences and consilience. Environmental Ethics, forthcoming.

Baumol, W.J., and W.E. Oates, 1988, The Theory of Environmental Policy. $2^{\text {nd }}$ ed. Cambridge University Press, Cambridge, UK.

Bergh, J.C.J.M. van den, 1996. Ecological Economics and Sustainable Development: Theory, Methods and Applications. Edward Elgar, Cheltenham.

Bergh, J.C.J.M. van den, and M.W. Hofkes (ed.), 1998. Theory and Implementation of Economic Models for Sustainable Development. Kluwer Academic Publishers, Dordrecht.

Bergh, J.C.J.M. van den, and R.A. de Mooij, 1996. An assessment of the growth debate. In: J.C.J.M. van den Bergh (ed.). Handbook of Environmental and Resource Economics. Edward Elgar, Cheltenham.

Bergh, J.C.J.M. van den, and J. van der Straaten (ed.), 1994. Toward Sustainable Development: Concepts, Methods and Policy, Island Press, Washington D.C.

Bergh, J.C.J.M. van den, and J. van der Straaten (ed.), 1997. Economy and Ecosystems in Change: Analytical and Historical Approaches. Edward Elgar, Cheltenham.

Bergh, JC.J.M. van den, and H. Verbruggen, 1999. Spatial sustainability, trade and indicators: an evaluation of the 'ecological footprint'. Ecological Economics 29(1), pp. 63-74.

Bergh, J.C.J.M. van den, A. Ferrer-i-Carbonell, and G. Munda, 2000. Alternative models of individual behaviour and implications for environmental policy. Ecological Economics 32(1): 43-61.

Blamey, R.K., and M.S. Common, 1999. Valuation and ethics in environmental economics In: J.C.J.M. van den Bergh (ed.) Handbook of Environmental and Resource Economics. Edward Elgar, Cheltenham.

Boulding, K.E., 1966. The economics of the coming spaceship earth. In: H. Jarret (ed.), Environmental Quality in a Growing Economy. Johns Hopkins University Press, Baltimore. 
Boulding, K.E., 1970. Economics as a Science. McGraw-Hill, London.

Boulding, K.E., 1978. Ecodynamics: A New Theory of Societal Evolution. Sage Publications, Beverly Hills.

Bruyn, S.M. de, and R.J. Heintz, 1999. The environmental Kuznets curve hypothesis. In J.C.J.M. van den Bergh (ed.). Handbook of Environmental and Resource Economics. Edward Elgar, Cheltenham.

Christensen, P.P., 1989. Historical roots for ecological economics: Biophysical versus allocative approaches. Ecological Economics 1(1): 17-36.

Ciriacy-Wantrup, S.V., 1952. Resource Conservation: Economics and Policies. University of California Press, Berkeley.

Clark, C.W., 1973. The economics of overexploitation. Science 181: 630-634.

Clark, C.W., 1990. Mathematical Bioeconomics: The Optimal Management of Renewable Resources. $2^{\text {nd }}$ ed. Wiley, New York.

Cleveland, C.J., D.I. Stern, and R. Costanza (eds.), 2000. The Economics of Nature and the Nature of Economics. Edward Elgar, Cheltenham, forthcoming.

Common, M., and C. Perrings, 1992. Towards an ecological economics of sustainability. Ecological Economics 6: 7-34.

Costanza, R., 1980. Embodied energy and economic valuation. Science 210: 1219-1224.

Costanza, R. (ed.), 1991. Ecological Economics: The Science and Management of Sustainability, Columbia University Press, New York.

Costanza, R., and H.E. Daly (eds.), 1987. Ecological Economics (Special issue). Ecological Modeling 38(1-2).

Costanza, R., and J. King, 1999. The first decade of Ecological Economics. Ecological Economics 28: 1-9.

Costanza, R., and C. Perrings, 1990. A flexible assurance bonding system for improved environmental management. Ecological Economics 2: 57-76.

Costanza, R., H.E. Daly, and J.A. Bartholomew, 1991. Goals, agenda and policy recommendations for ecological economics. In: R. Costanza (ed.). Ecological Economics: The Science and Management of Sustainability, Columbia University Press, New York.

Costanza, R., B.G. Norton, and B.D. Haskell (ed.), 1992. Ecosystem Health. Island Press, Washington D.C.

Costanza, R., O. Segura, and J. Martinez-Alier (ed.), 1996. Getting Down to Earth: Practical Applications of Ecological Economics. Island Press, Washington D.C.

Costanza, R., J. Cumberland, H. Daly, R. Goodland, and R. Norgaard, 1997a. An Introduction to Ecological Economics. Island Press, Washington D.C.

Costanza, R., C. Perrings, and C.J. Cleveland (ed.), 1997b. The Development of Ecological Economics, Edward Elgar, Cheltenham, UK.

Costanza, R., L. Wainger, C. Folke, and K.-G. Maler, 1993. Modeling Complex Ecological Economic Systems: Towards an Evolutionary, Dynamic Understanding of People and Nature. BioScience 43: 545-555.

Crocker, T.D., and J. Tschirhart, 1992. Ecosystems, externalities and economics. Environmental and Resource Economics 2: 551-567.

Cumberland, J.H, 1966. A regional inter-industry model for analysis of development objectives. Papers of the Regional Science Association 17: 65-95.

Daly, H.E., 1968. On economics as a life science. Journal of Political Economy 76: 392-406.

Daly, H.E., 1991. Steady-State Economics. $2^{\text {nd }}$ ed. Island Press, Washington D.C. (1 ${ }^{\text {st }}$ ed. 1977). 
Daly, H.E., 1992. Allocation, distribution, and scale: towards an economics that is efficient, just and sustainable. Ecological Economics 6: 185-193.

Daly, H.E., 1996. Beyond Growth: The Economics of Sustainable Development. Beacon Press, Boston.

Daly, H.E. (ed.), 1997. The contribution of Nicholas Georgescu-Roegen (Special issue). Ecological Economics 22(3).

Daly, H.E., 1999a. Globalization versus internationalization - some implications. Ecological Economics 31(1): 31-37.

Daly., H.E., 1999b. Ecological Economics and the Ecology of Economics: Essays in Criticism. Edward Elgar, Cheltenham.

Daly, H.E., and W. Cobb, 1989. For the Common Good: Redirecting the Economy Toward Community, the Environment and a Sustainable Future. Beacon Press, Boston.

Daly, H.E., and K.N. Townsend, 1993. Valuing the Earth: Economics, Ecology, Ethics. The MIT Press, Cambridge, MA.

Dasgupta, P.S., and G.M. Heal, 1979. Economic Theory and Exhaustible Resources. Cambridge University Press. Cambridge.

Duchin, F., and G.M. Lange, in association with K. Thonstad and A. Idenburg, 1994. The Future of the Environment: Ecological Economics and Technical Change. Oxford University Press, Oxford.

Edward-Jones, G., B. Davies, and S. Hussain, 2000. Ecological Economics: An Introduction. Blackwell Science, Oxford.

Ehrlich, P.R. 1968. The Population Bomb. Ballantine Books, New York.

Ekins, P., and M. Max-Neef (ed.), 1992. Real-life Economics: Understanding Wealth Creation. Routledge, London.

Faber, M., and J.L.R. Proops, 1990. Evolution, Time, Production and the Environment. SpringerVerlag, Heidelberg.

Fisher, A., 2000. Irreversibilities (Special issue). Resource and Energy Economics 22(3).

Folke, C., 1999. Ecological principles and environmental economic analysis. In: J.C.J.M. van den Bergh (ed.) Handbook of Environmental and Resource Economics. Edward Elgar, Cheltenham.

Galbraith, J.K., 1958. The Affluent Society. Houghton Mifflin, Boston.

Georgescu-Roegen, N., 1966. Analytical Economics: Issues and Problems. Harvard University Press, Cambridge MA.

Georgescu-Roegen, N., 1971. The Entropy Law and the Economic Process. Harvard University Press, Cambridge, MA.

Georgescu-Roegen, N., 1976. Energy and Economic Myths. Pergamon, New York.

Gibson, C.C., E. Ostrom, and T.K. Ahn, 2000. The concept of scale and the human dimensions of global change: a survey. Ecological Economics 32(2): 217-239.

Gowdy, J.M., 1994. Coevolutionary Economics: The Economy, Society and the Environment. Kluwer Academic Publishers, Dordrecht.

Gowdy, J.M. (ed.), 1998. Limited Wants, Unlimited Means: A Hunter-Gatherer Reader on Economics and the Environment. Island Press, Washington, D.C.

Gowdy, J.M., and A. Ferrer-i-Carbonell, 1999. Toward consilience between biology and economics: the contribution of Ecological Economics. Ecological Economics 29: 337-348.

Gowdy, J.M., and S. Mesner, 1998. The evolution of Georgescu-Roegen's bioeconomics. Review of Social Economy 56 (2): 136-156.

Graedel, T.E., and B.R. Allenby, 1995. Industrial Ecology. Prentice Hall, Englewood Cliffs, NJ. 
Gunderson, L.H., C.S. Holling, and S.S. Light (eds), 1995. Barriers and Bridges to the Renewal of Ecosystems and Institutions. Columbia University Press, New York.

Hardin, G., 1968. The tragedy of the commons. Science 162: 1243-1248.

Hartwick, J. M., 1977. Intergenerational equity and the investing of rents from exhaustible resources. American Economic Review 67: 972-974.

Herendeen, R.A., 1999. EMERGY, value, ecology and economics. In: J.C.J.M. van den Bergh (ed.). Handbook of Environmental and Resource Economics. Edward Elgar, Cheltenham.

Holling, C.S., 1973. Resilience and stability of ecological systems. Annual Review of Ecological Systems 4: 1-24.

Holling, C.S., 1986. The resilience of terrestrial ecosystems: Local surprise and global change. In: W. C. Clark and R. E. Munn (ed.). Sustainable development of the biosphere. Cambridge University Press, Cambridge.

Holling, C.S. (ed.), 1978. Adaptive Environmental Assessment and Management. Wiley, New York.

Hueting, R., 1980. New scarcity and economic growth: More welfare through less production? North-Holland, Amsterdam (Translated and updated from Dutch, 1974).

Isard, W., 1969. Some notes on the linkage of ecologic and economic systems. Papers of the Regional Science Association 22: 85-96.

Isard, W., 1972. Ecologic-Economic Analysis for Regional Development. The Free Press, New York.

Jansson, A.-M. (ed.), 1984. Integration of Economy and Ecology: An Outlook for the Eighties. Proceedings from the Wallenberg Conference on Energy and Economics. Sundt Offset, Stockholm.

Jansson, A.-M., M. Hammer, C. Folke, and R. Costanza (ed.), 1994. Investing in Natural Capital: The Ecological Economics Approach to Sustainability. Island Press, Washington D.C.

Kapp, K.W., 1950. The Social Costs of Private Enterprise. Harvard University Press, Cambridge, Mass.

Kneese, A.V. and J.L. Sweeney (ed.), 1985/1993. Handbook of Natural Resource and Energy Economics. Vol. 1-3. North-Holland, Amsterdam.

Krishnan, R., J.M. Harris, and N.R. Goodwin, 1995. A Survey of Ecological Economics. Island Press, Washington D.C.

Lee, K.N., 1993. Compass and Gyroscope: Integrating Science and Politics for the Environment. Island Press, Washington D.C.

Leontief, W.W., 1970. Environmental repercussions and the economic structure: An input-output approach. Review of Economic Studies 52: 262-271.

Levin et al. (17 authors), 1998. Resilience in natural and socioeconomic systems. Environment and Development Economics 3(2): 222-235.

Martinez-Alier, J., with K. Schluepmann, 1987. Ecological Economics: Environment, Energy and Society. $2^{\text {nd }}$ ed. Basil Blackwell, Oxford.

Martinez-Alier, J., 1999. Ecological economics. Unpublished Draft, September 1999. Forthcoming in International Encyclopedia of the Social and Behavioral Sciences.

Martinez-Alier, J., and M. O’Connor, 1999. Distribution issues: an overview. In: J.C.J.M. van den Bergh (ed.) Handbook of Environmental and Resource Economics. Edward Elgar, Cheltenham.

Martinez-Alier, J., G. Munda and J. O’Neill, 1998. Weak comparability of values as a foundation for ecological economics. Ecological Economics 26: 277-286. 
Meadows, D.H., D.L. Meadows, J. Randers, and W.W. Behrens III, 1972. The Limits to Growth. Universe Books, New York.

Mishan, E.J., 1967. The Cost of Economic Growth. Staples Press, London.

Mott, T., 2000. In Memoriam: Kenneth Boulding 1910-1993. The Economic Journal 110(464): 430-444.

Munasinghe, M., O. Sunkel, and C. de Miguel, 2000. The Sustainability of Long-Term Growth. Edward Elgar, Cheltenham, forthcoming.

Munda, G., P. Nijkamp, and P. Rietveld, 1994. Qualitative multi-criteria evaluation for environmental management. Ecological Economics 10: 97-112.

Neher, P.A., 1990. Natural Resource Economics: Conservation and Exploitation. Cambridge University Press, New York.

Norgaard, R.B., 1984. Coevolutionary development potential. Land Economics 60: 160-173.

Norgaard, R.B., 1985. Environmental Economics: An Evolutionary Critique and a Plea for Pluralism. Journal of Environmental Economics and Management 12: 382-394.

Norgaard, R.B., 1994. Development Betrayed: The End of Progress and a Coevolutionary Revisioning of the Future. Routledge, London and New York.

Norton, B., R. Costanza, and R. Bishop, 1998. The evolution of preferences: why 'sovereign' preferences may not lead to sustainable policies and what to do about it. Ecological Economics 24: 193-211.

Odum, H.T., 1971. Environment, Power, and Society. Wiley, New York.

Odum, H.T., 1987. Models for national, international and global systems policy. In: L.C. Braat and W.F.J. van Lierop (eds.). Economic-Ecological Modelling. North-Holland.

Page, T., 1977. Conservation and Economic Efficiency. Johns Hopkins University Press, Baltimore.

Perman, R., Y. Ma, J. McGilvray, and M. Common, 1999. Natural Resource and Environmental Economics. $2^{\text {nd }}$ ed. Addison-Wesley/Longman, London.

Perrings, C., 1998. Resilience in the dynamics of economy-environment systems. Environmental and Resource Economics 11: 503-520.

Pezzey, J., 1989. Economic Analysis of Sustainable Growth and Sustainable Development. Environmental Department Working paper no. 15, Environmental Department, The World Bank. Reprinted as J. Pezzey, 1992. Sustainable Development Concepts: An Economic Analysis. World Bank Environment Paper 2.

Pimm, S.L., 1984. The complexity and stability of ecosystems. Nature 307: 321-326.

Rawls, J., 1972. A Theory of Justice. Harvard University Press, Cambridge, Mass.

Ruth, M., and C.J. Cleveland, 1996. Modeling the dynamics of resource depletion, substitution, recycling and technical change in extractive industries. Ch. 15 in: R. Costanza, O. Segura and J. Martinez-Alier (ed.). Getting Down to Earth: Practical Applications of Ecological Economics. Island Press, Washington D.C.

Sagoff, M., 1988. The Economy of the Earth. Cambridge University Press, Cambridge.

Shogren, J.F., and C, Nowell, 1992. Economics and ecology: a comparison of experimental methodologies and philosophies. Ecological Economics 5: 101-126.

Siebert, H., 1995. Economics of the Environment: Theory and Policy, $4^{\text {th }}$ ed. Springer-Verlag, Berlin.

Socolow, R., C. Andrews, F. Berkhout, and V. Thomas (eds.) (1994). Industrial Ecology and Global Change. Cambridge University Press, Cambridge.

Solow, R.M., 1974. Intergenerational equity and exhaustible resources. Review of Economic Studies 41: 29-45. 
Solow, R.M., 1986. On the intergenerational allocation of natural resources. Scandinavian Journal of Economics 88: 141-149.

Spash, C., 1999. The development of environmental thinking in economics. Environmental Values 8: 413-435.

Spash, C., and N. Hanley 1995. Preferences, information and biodiversity preservation. Ecological Economics 12: 191-208.

Stern, D., 1997. Limits to substitution and irreversibility in production and consumption: a neoclassical interpretation of ecological economics. Ecological Economics 22: 197-215.

Toman, M.A., J. Pezzey, and J. Krautkraemer, 1995. Neoclassical economic growth theory and 'sustainability'. In: D. Bromley (ed.), Handbook of Environmental Economics. Blackwell, Oxford, 1994.

Turner, R.K., 1999. Environmental and ecological economics perspectives. In: J.C.J.M. van den Bergh (ed.) Handbook of Environmental and Resource Economics. Edward Elgar, Cheltenham.

Turner, R.K., C. Perrings, and C. Folke, 1997. Ecological economics: paradigm or perspective. In: J.C.J.M. van den Bergh and J. van der Straaten (ed.). Economy and Ecosystems in Change: Analytical and Historical Approaches. Edward Elgar, Cheltenham.

Vitousek, P.M., P.R. Ehrlich, A.H. Ehrlich, and P.A. Matson, 1986. Human appropriation of the products of photosynthesis. Bioscience 34: 368-373.

Wackernagel, M., and W. Rees, 1996. Our Ecological Footprint: Reducing Human Impact on the Earth. New Society Publishers, Gabriola Island, BC and Philadelphia, PA.

Walters, C., 1986. Adaptive Management of Renewable Resources. MacMillan, New York.

Wilkinson, R., 1973. Poverty and Progress: An Ecological Model of Economic Development. Methuen \& Co., London.

Wilson, E.O., 1998. Consilience. Alfred Knopf, New York.

Zuchetto, J., and A.M. Jansson, 1985. Resources and Society: A Systems Ecology Study of the Island of Gotland. Sweden. Springer-Verlag, New York. 


\section{Endnotes}

${ }^{1}$ The International Society for Ecological Economics (ISEE) was founded by participants at a workshop in Barcelona in 1987, while its roots go back at least to a meeting on the integration of economics and ecology in Sweden in 1982 (Jansson 1984). Spash (1999) and Martinez-Alier (1999) provide more details on the origins of ISEE. The journal Ecological Economics was founded in 1989 by R. Costanza and H.E. Daly, who are still its editorin-chief and associate editor, respectively. An early collection of articles aimed at defining ecological economics is Costanza and Daly (1987).

${ }^{2}$ Traditional environmental economics is based on neoclassical welfare theory and microeconomics. Its core insights are critically dependent on the assumption of rational individual behaviour (utility or profit maximisation), which together with an additional assumption of market clearing generates a unique economic equilibrium, that is, a unique combination of prices and tradable quantities of each product on each market (including the ones for labour and capital). Good introductions to traditional environmental economics are offered by Baumol and Oates (1988), Kneese and Sweeney (1985/1993) and Siebert (1995); a modern treatment, mixing traditional and ecological economics perspectives is Perman et al. (1999).

${ }^{3}$ Important contributions covering both criticism and alternatives include: Boulding (1978), Costanza (1991), Daly (1991), Daly and Cobb (1989), Daly and Townsend (1993), Ekins and Max-Neef (1992), Faber and Proops (1990), Georgescu-Roegen (1971), Norgaard (1994), and Sagoff (1988).

${ }^{4}$ In 1949 Boulding received the prestigious John Bates Clark Medal, awarded by the American Economics Association every two years to an outstanding economist under 40. In 1968 he was elected President of the American Economics Association (see Mott 2000).

${ }^{5}$ ERE in general emphasises uncertainty and instability within the economy (macroeconomic stability, business cycles) rather than environmental uncertainty. Nevertheless, ERE has made many contributions to studying environmental uncertainty in specific cases, notably in the context of climate change modelling, and related to the notions of option value and quasi-option value (see a special issue of Resource and Energy Economics on "Irreversibilities" (Fisher 2000).

${ }^{6}$ A reviewer noted an earlier comparison: namely, Table 1.1 in Costanza et al. (1991).

${ }^{7}$ In this context the discussion of GDP as a measure for "progress" and welfare is relevant. EE and ERE economists agree that GDP is unsuitable as a measure of social welfare. It is better interpreted as reflecting the (national) costs incurred to reach a certain level of national welfare. In other words, GDP growth means an increase of the national costs incurred to realise a decreasing or increasing welfare level. GDP was of course never meant as an indicator of welfare, but has, due to a lack of any good alternative, slowly adopted this role. Although a theoretical foundation for GDP as a measure for social welfare is completely lacking, trust in GDP growth has started to live its own life (e.g., on financial markets), resulting in GDP growth being strongly correlated with economic stability.

${ }^{8}$ The work of Ruth and Cleveland (1996), which focuses on the relation between extraction of mineral resources and fossil fuel (energy) resources, fits into this tradition. Extraction of resources is associated with a transformation of enormous amounts of energy, both in the extraction process itself and in subsequent processes, such as concentration, smelting, filtering and refining. In order to extract resources from supplies with low concentrations of a desired material, the amount of energy use per useful unit of output needs to rise, and increasingly so. This means that energy use will follow a progressive pattern over time. Technological improvements and recycling can slow down the unfolding of such a pattern, but not permanently postpone it. Such a type of EE model of extraction is less partial than the traditional, Hotelling type of ERE model (see Dasgupta and Heal 1979).

${ }^{9}$ For a variety of opinions about the Ecological Footprint, see the discussion in Ecological Economics 31(3), pp. 317-321, as well as the 12 contributions by economists and ecologists in the Forum of Ecological Economics 32(3), pp. 341-393.

${ }^{10}$ Spash (1999) notes that the European branch of the International Society for Ecological Economics tends to focus more on socio-economics and political economy (including philosophy, environmental ethics, institutional 
economics, sociology, and political ecology), whereas the American approach can be characterised as more scientific. The most fundamental issue raised by the European EE in this respect is perhaps that it looks for alternatives to free market systems, as these "... educate individuals to act as selfish hedonists and create self perpetuating power structures which reinforce inequity." (Spash, 1999, p. 428). Three journals: namely, Environmental Ethics, Environmental Politics, and Environmental Values, provide information regarding these alternative perspectives.

${ }^{11}$ In the USA, the distinction between ERE and EE is clearer than in Europe, presumably because ERE is more developed and more strictly applied. In Europe, there seems to be somewhat more room for pluralism and pragmatism, as well as for discussion of the shortcomings of ERE. 